\title{
A MAGYAR SPORTVÁLLALKOZÁSOK KIEGÉSZÍTŐ MELLÉKLETEINEK VIZSGÁLATA A MÉRLEGHEZ KAPCSOLÓDÓAN
}

\author{
Kerezsi Dóra - Erdey László
}

\section{Összefoglalás}

Napjainkban megnött és megváltozott a sport szerepe, mostanra az eredetileg civil, mozgáson alapuló, szabadidös magántevékenységböl egy külön területté vált. A sport az egyik legmeghatározóbb eleme a világgazdaságnak, folyamatosan újabb és újabb piacokat nyit meg, mely során megjelentek a profitorientált vállalatok is. Ezen iparág GDP-ben mérhetö hatása egyre nagyobb és eröteljesebb növekedést mutat. A mai globalizált és felgyorsult világban nélkülözhetetlen, hogy a vállalkozások naprakész információkkal rendelkezzenek. A gazdasági élet kihivásainak az a vállalat tud megfelelni, amely rendelkezik a szükséges információkkal. A nyilvános információk egyik forrása lehet a 2000. évi C. törvény elöírásai alapján elkészitett és közzétett számviteli beszámoló. A számviteli beszámoló három részböl áll, a mérlegböl, az eredménykimutatásból és a kiegészitö mellékletböl. A kiegészitö melléklet szöveges információi a számszerü adatok pontosabb értelmezéséhez szükségesek. A vállalatok hatékony müködéséhez, a megfelelö döntéshozatalhoz, a kockázatok értékeléséhez nyújthat segitséget egy-egy piaci szereplö (vevök, szállitók, versenytársak stb.) kiegészitö melléklete. Kutatásunkban azt vizsgáljuk, hogy a vállalatok által elkészitett kiegészitö mellékletek tartalmazzák-e azokat az információkat, amelyek segitségével a partner vállalatokra vonatkozó szükséges pénzügyi ismeretek megszerezhetök. A vizsgálathoz a 931-es TEÁOR számú, fôtevékenységként Sporttevékenységet megadó vállalatokat kiegészito" mellékleteit használtuk fel. Szövegbányászat segitségével azt vizsgáljuk, hogy a kiegészitö mellékletek mennyiben felelnek meg a számviteli törvény általi elöirásoknak.

Kulcsszavak: Sporttevékenység, Kiegészitö melléklet, Mérleg, Tájékoztatás, Adatbányászat

\section{JEL: Z2}




\title{
EXAMINATION OF SUPPLEMENT NOTES RELATED TO THE STATEMENT OF FINANCIAL POSITION AT HUNGARIAN SPORT COMPANIES
}

\begin{abstract}
Currently, the role of sports has intensified and changed; by now, it has become a separate area of interest from an originally civil, exercise-based, private leisure activity. Sport is one of the most decisive elements of global economy, constantly opening up new and emerging markets, causing profit-oriented companies to appear. The GDP-measurable impact of this industry shows a growing and increasing tendency. In the globalized and accelerated world of our time, it is essential that enterprises have up-to-date information. Only a company that is in possession of the necessary information is able to meet the challenges of business life. One source of public information might be the annual statement prepared and published in accordance with the stipulations of Act $C$ of 2000. The annual statement consists of three parts: the balance sheet, the profit and loss account and the notes to the financial statement. The text-based information of the notes to the financial statement are for the more accurate interpretation of numerical data. The notes to the financial statement of certain market participants (consumers, suppliers, competitors, etc.) might support efficient operation of companies, their proper decision-making and risk assessment. In our research, we examine whether the notes on the accounts of companies include the information, which could help obtain necessary financial knowledge concerning the partner companies. For the analyses, we used the notes on the accounts of companies, which have sports activity (Hungarian NACE No. 931) as their main line of business. By means of text mining, we analyse the extent to which the notes on the accounts are in conformity with the Accounting Act.
\end{abstract}

Keywords: Sports activity, Notes, Balance Sheet, Information, Text mining

JEL: Z2 


\section{Bevezetés}

A sport eredetileg civiltevékenységen alapuló magántevékenység volt, kialakulásakor jellemzője a nonprofit tevékenységü társasági forma volt. Nem volt fö célja a nyereség keletkezése és a profit maximalizálása, viszont kizáró ok sem volt. A középpontban a tranzakciós költségek csökkentése és a nyereség visszaforgatása volt (András et al. 2012). A sportvállalatok globalizációja, a gyakori honosítások és a nemzeti jellegüket tekintve nemzeti bajnokságok fontos következményei a hivatásos sport globalizációjának. Andreff (2008) szerint a sport gazdasági súlya GDP-arányosan jelentősen megnőtt. A sport mára nem csak helyi tevékenység, globalizálódott és világméretűvé nőtte ki magát, mint üzletágba a sportba egyre több tőkebefektetés kerül (Bácsné et. al. 2019).

A magyar sportfinanszírozást tekintve 2010 óta jelentős átalakuláson ment keresztül, melynek oka leginkább a sportba áramló pénznövekedés. A szövetségek és sportegyesületek ebből kifolyólag kiegyensúlyozott gazdasági körülmények között működnek (Gősi - Nagy, 2018). A változások leginkább az élsportot érintették, a szabadidősportot már kevésbé. (Eurobarometer, 2018). Mikro- és makro szinten a gazdasági oldalról a sporttevékenységnek jótékony a hatása, mint például költségcsökkentő az egészségesebb életmód (Müller-Bácsné 2018, Gabnai et. al. 2019), a rendezvényeknek turizmusélénkítő hatása van (Borbély-Müller 2015)), illetve vállalkozások működésével kapcsolatos pozitív gazdasági hatások (Gősi, 2019). A sport társadalmi hasznossága András (2014) szerint három nagyobb hatást különböztethetünk meg. Szorosan kapcsolódik a szabadidősport az egészségmegőrzéshez, így hosszú távú hatásai lehetnek. Sportolás időtartama alatt létrejött pillanatnyi örömforrás. Továbbá magasabb termelékenység előidézése az egészség által közvetlenül nyújtott haszon által.

Szabadidősport-piacokat tekintve a következőket különböztethetünk meg (Szabó, 2012) alapján:

- Sportszerek, sportfelszerelések, sportruházat piaca.

- Sportszakemberek piaca.

- Szponzorok piaca.

- Merchandising piac.

- Fogyasztói piac.

Ezeken túl fontos megvizsgálni nemzetgazdasági szempontból is a sport hatását. Pozitív hatást ér el mind közvetlen, mind közvetett módon. Közvetlenül általa javul a gazdaság teljesítőképessége, termelékenysége, ezzel növelve az adott ország GDPjét. Közvetett hatásként pedig költést generál, ezáltal munkahelyet teremt és növeli az ország adóbevételét (Gősi, 2019). Ehhez a témakörhöz szorosan kapcsolódik a munkahelyi egészségfejlesztés keretén belüli sportolás biztosítása, illetve annak támogatása is (Patakiné Bősze, 2018, Hidvégi et. al. 2017). 
További gazdasági és társadalmi következményei vannak a sporttevékenység megváltozott és megnövekedett szerepének Fóris - Bérces (2005) alapján:

- Megnőtt az igény az egyéni elfoglaltsághoz igazodó sportolási lehetőségek, azaz az egyéni sportok iránt (Molnár 2019, Müller et. al. 2019).

- Felvirágzott a sportszereket gyártó ipar (Mórik et. al. 201).

- Járulékos bevételeivel együtt hatalmas jövedelmeket biztosít a nagy világversenyek szervezése (Bíró et. al. 2017, Müller et. al. 2016).

- Sokan élnek magas életszínvonalon a sport hozadékából.

- A professzionális sport teljesítménybéli differenciálódása miatt a sportágak jelentős részénél a nemzeti bajnokságok feletti nemzetközi bajnoki rendszerek alakultak ki különböző kupa néven.

Az innováció szerepét hangsúlyozzák a sportban is, mivel napjainkban az innovatív gondolkodás és együttműködés egyre nagyobb szerepet tölt be a hazai kkv-k, multinacionális cégek versenyképességének növelésében. A sport területén a termékfejlesztésben a különböző profilok lehetővé teszik és igénylik az innovációs tartalmat, mely sikerességet biztosít az azt alkalmazó cégeknek (Könyves - Müller, 2007).

Gősi (2019) kutatása alapján elmondható, hogy a Nemzeti Adó- és Vámhivatal, valamint a Központi Statisztikai Hivatal - eltérően a Sporttörvénytől - minden olyan gazdálkodó szervezetet a sportvállalkozások közé sorol, amelynek a főtevékenysége sporttevékenység. A fötevékenység azonban nem utal arra, hogy az adott szervezet a versenysport vagy a szabadidősport területén tevékenykedik. A Sporttörvény valamint KSH/NAV eltérő megközelítési módja miatt a sem a versenysport, sem a szabadidősport területén müködő szervezetek számát nem tudjuk pontosan. A Nemzeti Adó- és Vámhivatal szerint 2010-ről 2016-ra a sportvállalkozás kategóriába tartozó szervezetek száma 5 448-ról 8 463-ra nőtt, az árbevételük pedig több mint a kétszeresére emelkedett. Az adatokat az éves társasági adóbevallások alapján szolgáltatta a hivatal, hét különböző TEÁR kódos főtevékenységet végző szervezet került bele. Ezek a szabadidős sporteszköz kölcsönzés, sport és szabadidős képzés, sportlétesítmény működtetése, sportegyesületi tevékenység, testedzési szolgáltatás, egyéb sporttevékenység és fizikai közérzetet javító szolgáltatás (Gősi, 2019).

A vállalkozások számviteli beszámolók alapján történő értékeléshez, összehasonlításhoz, befektetéshez szükséges adatokat és információkat a beszámoló részeként közzétett mérleg és eredménykimutatás számszaki adatain kívül a szöveges információkat is tartalmazó kiegészítő melléklet szolgáltatja. A számviteli törvény meghatározza a kiegészítő melléklet kötelező adattartalmát, viszont ez nem minden esetben kerül közzétételre kellő részletezettséggel (Fenyves et al., 2018; Fenyves et al., 2019). 


\section{Anyag és módszer}

A kutatásunk alapját szolgáló anyagához a fötevékenységként sporttevékenységet végző vállalkozásokat (931-es TEÁOR számú) vontunk be, amelyeknek székhelye Magyarországon található. Az adatbázisba a 2017-es lezért üzleti évvel rendelkező cégek kerültek bevonásra. Összesen $1747 \mathrm{db}$ cég volt az adatbázisba, viszont ennek a 92\%-a, 1616 db vállalkozás rendelkezett kiegészítő melléklettel, így továbbiakban 1616 db kiegészítő mellékletet tudtunk vizsgálni és értékelni. 131 db vállalkozás nem rendelkezett kiegészítő melléklettel, melynek két oka lehetséges, az egyik az, hogy olyan beszámolót készített az adott üzleti évre, melynek nem kötelező tartalmi eleme a kiegészítő melléklet, vagy egyszerűen nem töltötték fel ezt, ezzel nem tettek eleget a számviteli törvény elöírásainak.

Az elemzést az $\mathrm{R}$ statisztikai rendszer különböző csomagjainak a felhasználásával végeztük. A módszertan során szövegbányászat segítségével azt vizsgáljuk, hogy a kiegészítő mellékletek milyen mértékben biztosítják azokat az információkat, amelyek a megbízható és valós összekép bemutatásához elengedhetetlenek, valamint a mérleg megfelelő értelmezéséhez, használatához elengedhetetlenül szükségesek lennének.

\section{Eredmények}

A számvitelről szóló 2000 évi C törvény szerint a vállalkozások többféle beszámolótípus elkészítése közül választhatnak a tárgyévet megelőző két üzleti évben elért értékesítés nettó árbevétele, mérlegföösszeg és átlagosan foglalkoztatottak számától függően. Ezen beszámolótípusok közé tartozik az éves, az egyszerüsített éves, a mikrogazdálkodói egyszerűsített éves, az összevont (konszolidált) éves és az egyszerűsített beszámoló. Mindegyik beszámoló kötelező része a mérleg és az eredménykimutatás. Emellett az éves, az egyszerűsített éves és az összevont éves beszámoló kötelező eleme a kiegészítő melléklet is. A mérleg és az eredménykimutatás felépítését a törvény egyértelműen bemutatja és szabályozza, ezzel ellentétben a kiegészítő mellékletét nem. Csak a kötelezően közzéteendő tételeket, magyarázatokat, mérleghez és eredménykimutatáshoz kapcsolódó információkat mutatja be mind az éves, mind az egyszerűsített éves beszámolót készítő vállalkozások számára. A kiegészítő melléklet megfelelő elkészítése elengedhetetlen a külső piaci szereplők számára, hiszen ebből tájékozódhatnak a számszaki adatokon túl szöveges információkkal a vállalkozásokról. A kiegészítő mellékletnek tartalmaznia kell a mérleghez kapcsolódó információkat, méghozzá olyan sorrendben, ahogyan a mérlegtételek a mérlegben szerepelnek. A következőkben ezen információk előfordulását vizsgáljuk a sportvállalkozások körében. 


\begin{tabular}{|l|c|c|c|c|c|c|c|c|}
\hline \multirow{2}{*}{ Keresett kifejezés } & \multirow{2}{*}{ Szerepel } & \multicolumn{6}{|c|}{ Beszámoló típusa } \\
\cline { 3 - 10 } & & \multicolumn{2}{|c|}{ Éves } & \multicolumn{2}{c|}{$\begin{array}{c}\text { Egyszerüsített } \\
\text { éves }\end{array}$} & \multicolumn{2}{c|}{$\begin{array}{c}\text { Nem adott } \\
\text { meg }\end{array}$} & \\
\hline Vizsgált cégek & $\mathbf{1 6 1 6}$ & $\mathbf{1 0 0 , 0 \%}$ & $\mathbf{1 5 8}$ & $\mathbf{9 , 8} \%$ & $\mathbf{1 3 3 3}$ & $\mathbf{8 2 , 5 \%}$ & $\mathbf{1 2 5}$ & $7,7 \%$ \\
\hline $\begin{array}{l}\text { Mérleghez kapcsolódó } \\
\text { információk }\end{array}$ & 798 & $49,4 \%$ & 67 & $4,1 \%$ & 687 & $42,5 \%$ & 44 & $2,7 \%$ \\
\hline Eszközök összetétele & 154 & $9,5 \%$ & 19 & $1,2 \%$ & 126 & $7,8 \%$ & 9 & $0,6 \%$ \\
\hline Források összetétele & 176 & $10,9 \%$ & 20 & $1,2 \%$ & 144 & $8,9 \%$ & 12 & $0,7 \%$ \\
\hline
\end{tabular}

1. táblázat: A mérleghez kapcsolódó információk bemutatása a kiegészítő mellékletben beszámolótípus alapján

Forrás: Saját szerkesztés, 2019

A vizsgált vállalkozások 10\%-a készítette el a részletesebb és több információt tartalmazó éves beszámolót, a 83\%-a a kevésbé részletes egyszerüsített éves beszámolót. Ezen túl a sportvállalkozások 8\%-a nem jelenítette meg a kiegészítő mellékletében a közzétett beszámoló típusát.

A kiegészítő melléklet egy általánosan elfogadott felépítése alapján 4 nagyobb részre tagolható, az általános, a mérleghez kapcsolódó, az eredménykimutatáshoz kapcsolódó és a tájékoztató jellegű magyarázatokra. Ezen részek megjelenítése nem kötelező, viszont az átláthatóság és a tagoltság szempontjából érdemes kiemelni.

- A mérleghez kapcsolódó információk kifejezést a sportvállalkozások majdnem fele szerepeltette a kiegészítő mellékletébe (1616 db cégből 798 db). Az egyszerüsített éves beszámolót készítők 42,5\%-a, az éveset készítők 4,1\%-a, míg akik a beszámolótípust nem jelenítették meg, azok 2,7\%-a tette közzé a keresett kifejezést.

- A kiegészítő melléklet célja a vállalkozás vagyoni, pénzügyi és jövedelmi helyzetéről a megbízható és valós összkép bemutatása. Ebből kifolyólag a cégeknek kötelezően be kell mutatniuk az eszközök és a források összetételét ahhoz, hogy a vagyoni helyzetük megismerhetővé váljon. Ezt a két keresett kifejezést a kiegészítő mellékletek körülbelül 10\%-a tartalmazta. Az éves beszámolót készítők 1\%-a, míg az egyszerüsített éves készítők 8\%-a tette közzé. 
A mérleg eszköz oldalához kapcsolódó közzétételi kötelezettségek Kerezsi (2018) alapján:

- Immateriális javak, tárgyi eszközök mozgástáblája, halmozott értékcsökkenés mozgástáblája, elszámolt vagy visszaírt terven felüli értékcsökkenés és értékhelyesbítés mozgástáblája.

- Üzleti vagy cégérték és negatív üzleti vagy cégértékként kimutatott halasztott bevétel leírása, megszüntetése.

- Befektetett pénzügyi eszközök értékvesztésének mozgástáblája.

\begin{tabular}{|l|c|c|c|c|c|c|c|c|}
\hline \multirow{2}{*}{ Keresett kifejezés } & \multicolumn{2}{|c|}{ Szerepel } & \multicolumn{6}{c|}{ Beszámoló típusa } \\
\cline { 4 - 10 } & \multicolumn{2}{|c|}{} & \multicolumn{2}{|c|}{ Éves } & \multicolumn{2}{c|}{$\begin{array}{c}\text { Egyszerüsített } \\
\text { éves }\end{array}$} & \multicolumn{2}{c|}{ Nem adott meg } \\
\hline Vizsgált cégek & $\mathbf{1 6 1 6}$ & $\mathbf{1 0 0} \%$ & $\mathbf{1 5 8}$ & $\mathbf{1 0} \%$ & $\mathbf{1 3 3 3}$ & $\mathbf{8 2 , 5} \%$ & $\mathbf{1 2 5}$ & $\mathbf{7 , 7} \%$ \\
\hline Befektetett eszközök & 1174 & $73 \%$ & 115 & $7 \%$ & 975 & $60,3 \%$ & 84 & $5,2 \%$ \\
\hline Immateriális javak & 1079 & $67 \%$ & 122 & $8 \%$ & 882 & $54,6 \%$ & 75 & $4,6 \%$ \\
\hline Tárgyi eszközök & 1419 & $88 \%$ & 149 & $9 \%$ & 1176 & $72,8 \%$ & 94 & $5,8 \%$ \\
\hline $\begin{array}{l}\text { Befektetett pénzügyi } \\
\text { eszközök }\end{array}$ & 520 & $32 \%$ & 71 & $4 \%$ & 420 & $26,0 \%$ & 29 & $1,8 \%$ \\
\hline
\end{tabular}

2. táblázat: A befektetett eszközökhöz kapcsolódó közzétételek bemutatása a kiegészítő mellékletben beszámolótípus alapján

Forrás: Saját szerkesztés, 2019

A 2. táblázatban szerepelnek a befektetett eszközök, immateriális javak, tárgyi eszközök és befektetett pénzügyi eszközök kifejezések kiegészítő mellékletben történő előfordulása a sportvállalkozások körében.

- A befektetett eszközök kifejezés a sportvállalkozások kiegészítő mellékletének 73\%-ában volt jelen. Az éves beszámolót készítők 7\%-a, az egyszerüsített éves beszámolót 60\%-a tette közzé, míg plusz 5\%-uk, akik pedig a beszámolótípust nem adták meg, viszont a befektetett eszközöket igen.

- A befektetett eszközökön belül a nem anyagi eszközöket, vagyis az immateriális javakat is kötelezően közzé kell tenni a vállalatoknak, amit a 67\%-a mutatott be. Az éves beszámolót készítők 8\%-a, az egyszerüsített éves beszámolót készítőknek pedig az 55\%-a. 
- A tárgyi eszközökkel kapcsolatosan is kötelező közzétenni számos információt. Ezt a kifejezést a kiegészítő mellékletek 88\%-a tartalmazta, az éves beszámolók kiegészítő mellékleteinek 9\%-ában, míg az egyszerüsített éves kiegészítő mellékletének a 73\%-ában szerepelt.

- Végül a befektetett pénzügyi eszközök kifejezést már jóval kevesebben mutatták be a beszámolójukban, az 1616 db vállalkozás 32\%-a, ahol 4\%-a éves, 26\%-a pedig egyszerűsített éves beszámolót készített.

A forgóeszközökön belül kötelezően közzé kell tenni a Számviteli törvény (2019) szerint:

- Követelések eredeti értéke, az üzleti évben elszámolt, visszaírt, halmozottan elszámolt értékvesztés összege mérlegtételek szerinti megbontásban.

- A készletek, értékpapírok értékelése kapcsán elszámolt értékvesztés mozgástáblája mérlegtételek szerinti megbontásban.

- Értékpapír típusonként azok értékesítése, beváltása, törlesztése kapcsán nettó módon elszámolt ráfordítások és bevételek bruttó összege.

- Visszavásárolt saját részvény, üzletrész megszerzésére vonatkozó adatok, megszerzésének indoka, számuk, névértékük, jegyzett tőkéhez viszonyított arányuk, visszterhes megszerzésük vagy elidegenítésük esetén kifizetett vagy kapott ellenérték.

\begin{tabular}{|c|c|c|c|c|c|c|c|c|}
\hline \multirow{3}{*}{$\begin{array}{c}\text { Keresett kifejezés } \\
\text { Vizsgált cégek } \\
\end{array}$} & \multirow{2}{*}{\multicolumn{2}{|c|}{ Szerepel }} & \multicolumn{6}{|c|}{ Beszámoló típusa } \\
\hline & & & \multicolumn{2}{|c|}{ Éves } & \multicolumn{2}{|c|}{$\begin{array}{c}\text { Egyszerüsített } \\
\text { éves }\end{array}$} & \multicolumn{2}{|c|}{ Nem adott meg } \\
\hline & 1616 & $100,0 \%$ & 158 & $9,8 \%$ & 1333 & $82,5 \%$ & 125 & $7,7 \%$ \\
\hline Forgóeszközök & 1139 & $70,5 \%$ & 118 & $7,3 \%$ & 938 & $58,0 \%$ & 83 & $5,1 \%$ \\
\hline Készletek & 1204 & $74,5 \%$ & 124 & $7,7 \%$ & 1008 & $62,4 \%$ & 72 & $4,5 \%$ \\
\hline Követelések & 1402 & $86,8 \%$ & 141 & $8,7 \%$ & 1174 & $72,6 \%$ & 87 & $5,4 \%$ \\
\hline Értékpapírok & 581 & $36,0 \%$ & 71 & $4,4 \%$ & 477 & $29,5 \%$ & 33 & $2,0 \%$ \\
\hline Pénzeszközök & 963 & $59,6 \%$ & 118 & $7,3 \%$ & 789 & $48,8 \%$ & 56 & $3,5 \%$ \\
\hline
\end{tabular}

3. táblázat: A forgóeszközökhöz kapcsolódó közzétételek bemutatása a kiegészítő mellékletben beszámolótípus alapján

Forrás: Saját szerkesztés, 2019

A 3. táblázatban szerepel a forgóeszközök, készletek, követelések, értékpapírok és pénzeszközök kifejezés előfordulásának és annak gyakorisága a vizsgált $1616 \mathrm{db}$ kiegészítő mellékletben.

- A forgóeszközök kifejezést az 1616 db vállalkozásból 1139 db szerepeltette, ez a 71\%-a. Ebből 7\%-a éves, 58\%-a egyszerüsített éves beszámolót készít, 
további 5\%-a pedig közzétette, viszont a beszámolótípust nem mutatta be.

- A forgóeszközökön belül a készletek kifejezés az 1616 db vállalkozás 75\%ának a kiegészítő mellékletében volt jelen, ebből 8\%-uk éves, 62\%-uk egyszerüsített éves beszámolót készített, további 4,5\%-uk pedig nem adta meg az elkészített beszámoló típusát.

- A követelések kifejezést a vizsgált sportvállalkozások 87\%-a mutatta be, ebből 9\%-uk éves, 73\%-uk egyszerüsített éves beszámoló részeként közzétett kiegészítő mellékletben szerepeltette, illetve további 5\%-uk pedig szintén szerepeltette csak a beszámolótípusa nem ismert.

- Az értékpapírok esetében a legkedvezőtlenebb a helyzet a forgóeszközökön belül, csupán a vállalkozások 36\%-a szerepeltette ezt a kifejezést. Az éves beszámolót készítők 4\%-a, az egyszerüsített éves beszámolót készítőknek pedig majdnem 30\%-a mutatta be.

- Végezetül a pénzeszközök kifejezés az 1616 db sportvállalkozás kiegészítő mellékletének majdnem 60\%-ában volt jelen. Az éves beszámolót készítők 7\%-a, az egyszerüsített évesnek pedig 50\%-a mutatta be.

A forrás oldalt megvizsgálva a vállalat saját forrásával kapcsolatban is vannak kötelező közzétételi kötelezettségei a vállalatoknak a kiegészítő mellékletben. A számviteli törvény (2019) alapján:

- Saját tőke üzleti éven belüli változása, annak okai.

- Jegyzett tőkén belül milyen értéket képvisel az anyavállalat, leányvállalat, közös vezetésű vállalkozás, társult vállalkozás.

- Lekötött tartalék jogcímenkénti megbontásban.

\begin{tabular}{|l|c|c|c|c|c|c|c|c|}
\hline \multirow{2}{*}{ Keresett kifejezés } & \multicolumn{2}{|c|}{ Szerepel } & \multicolumn{6}{c|}{ Szerepel } \\
\cline { 4 - 9 } & & \multicolumn{2}{|c|}{ Éves } & \multicolumn{2}{c|}{ Egyszerüsített éves } & \multicolumn{2}{c|}{ Nem adott meg } \\
\hline \multirow{2}{*}{ Vizsgált cégek } & $\mathbf{1 6 1 6}$ & $\mathbf{1 0 0 , 0 \%}$ & $\mathbf{1 5 8}$ & $\mathbf{9 , 8} \%$ & $\mathbf{1 3 3 3}$ & $\mathbf{8 2 , 5 \%}$ & $\mathbf{1 2 5}$ & $\mathbf{7 , 7 \%}$ \\
\hline Saját töke & 1277 & $79,0 \%$ & 120 & $7,4 \%$ & 1068 & $66,1 \%$ & 89 & $5,5 \%$ \\
\hline Jegyzett tóke & 996 & $61,6 \%$ & 113 & $7,0 \%$ & 832 & $51,5 \%$ & 51 & $3,2 \%$ \\
\hline Tóketartalék & 501 & $31,0 \%$ & 62 & $3,8 \%$ & 413 & $25,6 \%$ & 26 & $1,6 \%$ \\
\hline Eredménytartalék & 822 & $50,9 \%$ & 94 & $5,8 \%$ & 688 & $42,6 \%$ & 40 & $2,5 \%$ \\
\hline Lekötött tartalék & 715 & $44,2 \%$ & 85 & $5,3 \%$ & 600 & $37,1 \%$ & 30 & $1,9 \%$ \\
\hline Adózott eredmény & 979 & $60,6 \%$ & 111 & $6,9 \%$ & 806 & $49,9 \%$ & 62 & $3,8 \%$ \\
\hline
\end{tabular}

4. táblázat: A saját tőkéhez kapcsolódó közzétételek bemutatása a kiegészítő mellékletben beszámolótípus alapján

Forrás: Saját szerkesztés, 2019 
- A saját tőke kifejezés a sportvállalkozások kiegészítő mellékleteinek 79\%ában volt jelen. Ebből 7\%-uk éves, 66\%-uk pedig egyszerüsített éves beszámolót készít.

- A jegyzett tőke kifejezést a vállalatok 62\%-a mutatta be, ebből éves beszámolót készítőknek 7\%-a, míg egyszerüsített évest készítőknek 51\%-a tette közzé.

- A tartalékok közül a saját tőkén belül a tőketartalék kifejezést az $1616 \mathrm{db}$ vállalkozás 31\%-a mutatta be, ebből 3,8\% éves, 26\% egyszerüsített éves beszámoló részeként közzétett kiegészítő mellékletben.

- Az előző évek felhalmozott eredményeit bemutató eredménytartalék kifejezés a kiegészítő mellékletek kicsivel több, mint a felében szerepelt. Ebből 6\%-uk éves, 43\%-uk egyszerüsített éves beszámolót tett közzé.

- A lekötött tartalék kifejezés ennél kicsivel kevesebb kiegészítő mellékletben szerepel, az 1616 db vizsgált vállalkozás 44\%-ában. Ebből 5\% éves, míg 37\% egyszerüsített éves beszámolót készített.

- A tárgyévi eredmény, azaz adózott eredmény kifejezés a vizsgált kiegészítő mellékletek 61\%-ában volt jelen. 7\%-uk éves, míg 50\%-uk egyszerüsített éves beszámolót készített.

A céltartalékkal és a kötelezettségekkel kapcsolatban a számviteli törvény elöírásai alapján a következőket kell a vállalkozásoknak a kiegészítő mellékletükben közzétenni:

- Képzett céltartalék, illetve annak felhasználása jogcímenkénti megbontásban.

- A rövid lejáratú kötelezettségek egy üzleti évet meg nem haladó lejáratra kapott kölcsön, hitel, a hősszú lejáratú kötelezettségekből az üzleti éven belül esedékes törlesztések.

- Kötvénykibocsátásból és váltótartozásból származó kötelezettség visszafizetendő része abban az esetben, ha az nagyobb a kapott összegnél.

- Pénzügyi helyzet értékelése szempontjából jelentőséggel bíró kötelezettségek teljes összege (például jövőbeli nyugdíjfizetési, végkielégítési kötelezettség). 


\begin{tabular}{|l|c|c|c|c|c|c|c|c|}
\hline \multirow{2}{*}{ Keresett kifejezés } & \multicolumn{2}{|c|}{ Szerepel } & \multicolumn{6}{c|}{ Beszámoló típusa } \\
\cline { 4 - 9 } & & \multicolumn{2}{|c|}{ Éves } & \multicolumn{2}{c|}{ Egyszerúsített éves } & \multicolumn{2}{c|}{ Nem adott meg } \\
\hline \multicolumn{1}{|c|}{ Vizsgált cégek } & $\mathbf{1 6 1 6}$ & $\mathbf{1 0 0 , 0} \%$ & $\mathbf{1 5 8}$ & $\mathbf{9 , 8} \%$ & $\mathbf{1 3 3 3}$ & $\mathbf{8 2 , 5 \%}$ & $\mathbf{1 2 5}$ & $\mathbf{7 , 7 \%}$ \\
\hline Céltartalékok & 608 & $37,6 \%$ & 69 & $4,3 \%$ & 498 & $30,8 \%$ & 41 & $2,5 \%$ \\
\hline Kötelezettségek & 1517 & $93,9 \%$ & 149 & $9,2 \%$ & 1259 & $77,9 \%$ & 109 & $6,7 \%$ \\
\hline $\begin{array}{l}\text { Hosszú lejáratú } \\
\text { kötelezettségek }\end{array}$ & 588 & $36,4 \%$ & $36,4 \%$ & 72 & $4,5 \%$ & 476 & $29,5 \%$ & $2,5 \%$ \\
\hline $\begin{array}{l}\text { Rövid lejáratú } \\
\text { kötelezettségek }\end{array}$ & 894 & $55,3 \%$ & $55,3 \%$ & 95 & $5,9 \%$ & 724 & $44,8 \%$ & $4,6 \%$ \\
\hline
\end{tabular}

4. táblázat: A céltartalékhoz és kötelezettségekhez kapcsolódó közzétételek bemutatása a kiegészítő mellékletben beszámolótípus alapján

Forrás: Saját szerkesztés, 2019

- Az óvatosság elve miatt képzett céltartalékok bemutatása kötelező az éves és egyszerüsített éves beszámolót készítő cégek számára. A kifejezést mindöszsze a vizsgált sportvállalkozások 38\%-a mutatta be, amelyből 4\% éves, 31\% egyszerüsített éves beszámolót tett közzé.

- A kötelezettségek kifejezést majdnem minden cég bemutatta a kiegészítő mellékletében, 94\%-ában szerepel. Ebből 9\%-uk készített éves, míg 78\%-uk egyszerüsített éves beszámolót.

- A kötelezettségeket tovább bontva az egy évnél hosszabb lejáratú kötelezettségeket, azaz a hosszú lejáratúakat már csak 36\%-a mutatta be a megjegyzésekben, amelyből 4,5\%-a éves és 30\%-a egyszerüsített éves beszámolót tett közzé.

- Továbbá az egy évnél rövidebb futamidejű kötelezettségekről is kell információt szolgáltatni a cégeknek, a rövid lejáratú kötelezettségek kifejezés a vállalkozásoknak több mint a fele megjelenítette a kiegészítő mellékletében. Az éves beszámolót készítők 6\%-a, az egyszerüsített éves beszámolót készítőknek pedig a 45\%-a.

Az egyik számviteli alapelv az időbeli elhatárolások elve, amely kimondja, hogy az olyan gazdasági események kihatását, amelyek két vagy több üzleti évet (elszámolási időszakot) is érintenek, az adott időszak bevételei és költségei között olyan arányban kell elszámolni, ahogyan az alapul szolgáló időszak megoszlik az elszámolási időszakok között. A törvény alapján kötelező közzétenni a jelentős összegeit a bevételek aktív időbeli elhatárolásának, halasztott ráfordításának, költségek és ráfordítások passzív időbeli elhatárolásának és halasztott bevételeknek (Számviteli törvény, 2019). 


\begin{tabular}{|c|c|c|c|c|c|c|c|c|}
\hline \multirow{2}{*}{ Keresett kifejezés } & \multicolumn{2}{|c|}{ Szerepel } & \multicolumn{5}{c|}{ Beszámoló típusa } \\
\cline { 4 - 9 } & \multicolumn{2}{|c|}{ Éves } & \multicolumn{2}{c|}{ Egyszerúsített éves } & \multicolumn{2}{c|}{$\begin{array}{c}\text { Nem adott } \\
\text { meg }\end{array}$} \\
\hline Vizsgált cégek & $\mathbf{1 6 1 6}$ & $\mathbf{1 0 0 , 0} \%$ & $\mathbf{1 5 8}$ & $\mathbf{9 , 8} \%$ & $\mathbf{1 3 3 3}$ & $\mathbf{8 2 , 5 \%}$ & $\mathbf{1 2 5}$ & $\mathbf{7 , 7 \%}$ \\
\hline $\begin{array}{l}\text { Aktív idóbeli } \\
\text { elhatárolások }\end{array}$ & 763 & $47,2 \%$ & 81 & $5,0 \%$ & 646 & $40,0 \%$ & 36 & $2,2 \%$ \\
\hline $\begin{array}{l}\text { Passzív időbeli } \\
\text { elhatárolások }\end{array}$ & 746 & $46,2 \%$ & 85 & $5,3 \%$ & 621 & $38,4 \%$ & 40 & $2,5 \%$ \\
\hline
\end{tabular}

5. táblázat: Az elhatárolásokhoz kapcsolódó közzétételek bemutatása a kiegészítő mellékletben beszámolótípus alapján

Forrás: Saját szerkesztés, 2019

Mind az aktív, mind a passzív időbeli elhatárolás kifejezést a vizsgált sporttevékenységet végző vállalkozások 46-47\%-a tette közzé a kiegészítő mellékletében. A vizsgált cégekből éves beszámolót készítő 5\%, egyszerüsített évest pedig 40\%. További $2 \%$-uk pedig nem mutatta be a beszámolótípusát.

\begin{tabular}{|l|c|c|c|c|c|c|c|c|}
\hline \multirow{2}{*}{ Keresett kifejezés } & \multicolumn{2}{|c|}{ Szerepel } & \multicolumn{6}{|c|}{ Beszámoló típusa } \\
\cline { 4 - 10 } & & \multicolumn{2}{|c|}{ Éves } & \multicolumn{2}{c|}{ Egyszerúsített éves } & \multicolumn{2}{c|}{ Nem adott meg } \\
\hline Vizsgált cégek & $\mathbf{1 6 1 6}$ & $\mathbf{1 0 0 , 0} \%$ & $\mathbf{1 5 8}$ & $\mathbf{9 , 8} \%$ & $\mathbf{1 3 3 3}$ & $\mathbf{8 2 , 5 \%}$ & $\mathbf{1 2 5}$ & $\mathbf{7 , 7 \%}$ \\
\hline Zálogjog & 609 & $37,7 \%$ & 48 & $3,0 \%$ & 511 & $31,6 \%$ & 50 & $3,1 \%$ \\
\hline Mérlegen kívüli tétel & 173 & $10,7 \%$ & 20 & $1,2 \%$ & 149 & $9,2 \%$ & 4 & $0,2 \%$ \\
\hline
\end{tabular}

6. táblázat: Egyéb mérleghez kapcsolódó közzétételek bemutatása a kiegészítő mellékletben beszámolótípus alapján

Forrás: Saját szerkesztés, 2019

Végezetül a törvény szerint közzé kell még tenni a vállalkozásoknak (Számviteli törvény, 2019):

- Több, mint 5 éves futamidejü, valamint zálogjoggal vagy hasonló joggal biztosított kötelezettségek teljes összege és a biztosítékok fajtája.

- Mérlegen kívüli tételként a függő és biztos jövőbeni kötelezettségvállalások összege fajtánként (opciós és swap ügyletek esetében).

- Mérlegen kívüli egyéb tételek. 
A 7. táblázatban a zálogjog kifejezés és a mérlegen kívüli tétel kifejezés bemutatása a kiegészítő mellékletben kerül bemutatásra. A zálogjog a vizsgált cégek 38\%-ban volt jelen, ebből 3\%-a éves, 32\%-a egyszerüsített éves beszámolót készített. A mérlegen kívüli tétel kifejezés pedig csupán a kiegészítő mellékletek 11\%-ában volt jelen. Ebből 1\%-uk éves, 9\%-uk egyszerüsített éves beszámolót készített.

\section{Következtetések, javaslatok}

Kutatásunkban a hazai sportvállalkozások kiegészítő mellékleteinek mérleghez kapcsolódó részeit vizsgáltuk. Célunk volt felmérni, hogy megfelelnek e a törvényi előírásoknak, azaz tartalmazzák-e azokat a kifejezéseket, amelyeket a számviteli törvény kötelezően előír. Az eredmények fejezetben jól látható, hogy számos hiányossággal találkozhatunk a sportvállalkozások kiegészítő mellékletének mérleghez kapcsolódó közzétételi kötelezettségeivel kapcsolatban. Fontos kiemelni, hogy a fentebb bemutatott eredmények kapcsán csak azt vizsgáltuk, hogy ezen kifejezések az 1616 db vállalkozás kiegészítő mellékletében előfordul-e. Viszont ez még nem azt jelenti, hogy a törvényi elöírásoknak 100\%-osan meg is felelnek, hiszen a tényleges tartalma nem került vizsgálatra. Fontos az, hogy az egyes kötelező tételeket és mutatószámokat ne csak bemutassa a vállalkozás, hanem plusz információt és magyarázatot tegyen közzé velük kapcsolatban, hiszen a külső piaci szereplők számára ez nyújt leginkább hasznos információt.

\section{Hivatkozott források}

[1.] Andár K. - Havran Zs. - Jandó Z. (2012): Üzleti globalizáció és a hivatásos sport: sportvállalatok nemzetközi szerepvállalása. TM 14. sz. műhelytanulmány, Budapesti Corvinus Egyetem, 23 o. ISNN 1787-6915.

[2.] Adrás K. (2014): A szabadidősport gazdálkodástana. In.: Perényi, Sz. (szerk): A mozgás szabadsága: A szabadidősport társadalmi, gazdasági és egészségügyi megközelítései. Debrecen. 16- 34

[3.] Andreff W. (2008): Globalization of the sport economy; Rivista Di Diritto Ed Economia Dello Sport Vol. IV, Fasc. 3, 2008.

[4.] Bácsné B. É. - Fenyves V. - Szabados Gy. - Dajnoki K. - Müller A. -Bács Z. (2019): A sportágazat nemzetgazdasági jelentőségének vizsgálata beszámoló adatok alapján 2014-2016-os időszakban. Jelenkori Társadalmi és Gazdasági Folyamatok 13 : 3-4 pp. 93-103. 
[5.] Biró M. - Müller A. - Ráthonyi Ó. K . - Ráthonyi G. -Éva, Bácsné B. É. - Dobay B. (2017): Az olimpiai játékok örökségei, különös tekintettel a gazdasági és társadalmi hatásokra. Selye E-Studies $8: 1$ pp. 51-63.

[6.] Borbély A. - Müller A (2015):Sport és turizmus. Debrecen, Magyarország : Campus Kiadó (2015) , 110 p. ISBN: 9789639822368

[7.] Eurobarometer (2018): Special Eurobarometer 472. Sport and Physical activity. https://ec.europa.eu/health/nutrition_physical_activity/eurobarometers_hu

[8.] Fenyves V. - Bács Z. - Zéman Z. - Böcskei E. - Tarnóczi T. (2018):The Role of The Notes to the Financial Statements in Corporate Decision-Making. Corporate Ownership and Control $15: 4$ pp. 138-148. , 11 p.

[9.] Fenyves V. - Böcskei E. - Bács Z. - Zéman Z. - Tarnóczi T (2019): Analysis of the notes to the financial statement related to balance sheet in case of hungarian information-technology service companies Scientific annals of economics and business $66: 1$ pp. 27-39. , 13 p. (2019)

[10.] Fóris - Bérces (2005): Sport, gazdaság, terminológia, Tudásmenedzsment, A Pécsi Tudományegyetem Felnőttképzési és Emberi Erőforrás Fejlesztési Karának periodikája VI. évfolyam 2. szám 2005. november, 117-127 o., ISSN 1586-0698.

[11.] Gabnai Z. - Müller A. - Bács Z. - Bácsiné B. É. (2019):A fizikai inaktivitás nemzetgazdasági terhei. Egészségfejlesztés $60: 1$ pp. 20-30. ,

[12.] Gősi Zs. - Nagy J. (2018): Sportvállalkozások gazdálkodási jellemzői,. In.: Mozgásbiológia- sport-tudomány. Tanulmányok a 47. Mozgásbiolgóia Konferencia előadásaiból. Budapest, Magyar Edzők Társasága. 100-110

[13.] Gősi Zs. (2019): A szabadidősport néhány gazdasági hatása. Sokszínű rekreáció, Tanulmányok a rekreáció témaköréből, Budapest, ELTE PPK, 69-85 o. ISBN: 978-963-489-111-6.

[14.] Hidvégi P. - Bíró M. - Müller A. - Váczi P. (2017): Testnevelési program a munkahelyi egészségfejlesztésben. Acta Academiae Paedagogicae Agriensis Nova Series: Sectio Sport 44 pp. 115-138. , 24 p. (2017)

[15.] Könyves E. - Müller A. (2007). A minőségi díj megítélése az egészségturisztikai szolgáltatók marketingkommunikációs eszközrendszerében. Acta Academiae Pedagogicae Agriensis. XXXIV. Kötet. 57-71.o.

[16.] Molnár A. (2019) :Fitnesz trendek az egészség szolgálatában.In: Bácsné, Bába Éva; Müller, Anetta (szerk.) „Mozgással az egészségért” A fizikai aktivitás jelentősége a jövő munkavállalóinak egészségmegőrzésében : Nemzetkö- 
zi Konfe rencia és Workshop: Válogatott tanulmánykötet = „Movement for health" The importance of physical activity in health protection of future workers: International Conference and Workshop: Proceedings from the International Conference and WorkshopDebrecen, Magyarország : Debreceni Egyetem, (2019) pp. 113-120. , 8 p.

[17.] Mórik K.V. - Bácsné B. É. - Müller A. -Ráthonyi G. - Molnár A. (2019):The appearance of product innovation in the life of a Hungarian SMEs in the global market of sporting goods - implications from a research. Geosport for Society $10: 1$ pp. 25-38.

[18.] Müller A. - Bácsné B. É (2018): Az egészséges életmód és a sport kapcsolata. Létavértes, Magyarország: Létavértes SC '97 Egyesület (2018), 96 p. ISBN: 9786150031897.

[19.] Müller A. - Biró M. - Ráthonyi Ok.. - Ráthonyi G. - Széles K. GY. Boda E. -Macra-Osorhean M. D. - Andras Á. (2017): Economic impacts of sports events. Studia Universitatis Babes-Bolyai Educatio Artis Gymnasticae LXI : 4 pp. 85-95. , 11 p. (2016)

[20.] Müller A. -Lengyel A. - Koroknay Zs. - Molnár A. (2019):Népszerű fitnesz mozgásformák.In: Bácsné, Bába Éva; Müller, Anetta (szerk.) „Mozgással az egészségért” A fizikai aktivitás jelentősége a jövő munkavállalóinak egészségmegőrzésében : Nemzetközi Konferencia és Workshop: Válogatott tanulmánykötet $=$ „Movement for health” The importance of physical activity in health protection of future workers: International Conference and Workshop: Proceedings from the International Conference and Workshop.Debrecen, Magyarország : Debreceni Egyetem, (2019) pp. 106-112.

[21.] Patakiné Bősze J. (2018): A munkahelyi egészségfejlesztés magyarországi tevékenységprofiljának bemutatása. In: II. Sport és Innováció Nemzetközi Konferencia. Absztrakt kötet. Budapest: Magyar Testnevelési Egyetem, Magyar Nemzeti Kereskedőház 89.

[22.] Szabó Á. (2012): A magyar szabadidősport működésének vizsgálata. Piacok, értékteremtés, feladatok a szabadidősportban. Ph.D. értékezés. Budapesti Corvinus Egyetem 


\section{Szerzők:}

\section{Kerezsi Dóra}

PhD Hallgató

Ihrig Károly Gazdálkodás- és Szervezéstudományok Doktori Iskola

Debreceni Egyetem, Gazdaságtudományi kar

Számviteli és Pénzügyi Intézet, Kontrolling nem önálló Tanszék

kerezsi.dora@econ.unideb.hu

\section{Erdey László}

egyetemi docens

Debreceni Egyetem, Gazdaságtudományi kar

Világgazdasági és Nemzetközi Kapcsolatok Intézet

erdey.laszko@econ.unideb.hu

" Az Emberi Erőforrások Minisztériuma ÚNKP-I9-3 KóDSZÁMÚ ÚJ Nemzeti Kiválóság ProgramjánaK támogatásÁval KÉszüLT" 